\title{
Basaloid Squamous Cell Carcinoma
}

\author{
Jasim Radhi \\ Department of Pathology and \\ Molecular Medicine McMaster University \\ Hamilton, Ontario \\ Canada
}

\section{Introduction}

Squamous cell carcinoma is the second most common cancer of the skin. This tumor arises predominantly in sun exposed actinically damaged areas. Implicated as predisposing factors, in addition to sunlight, these are industrial carcinogens, chronic ulcers, and ionizing radiation [1]. They are common cancer in immunocompromised and renal transplant patients [2]. Squamous cell carcinomas are known to be the most prevalent malignant tumor of the head and neck region [3]. They are also reported in many organs including cervix, lung, bladder, uterus, ovary, esophagus and teratomas $[4 ; 5 ; 6,7]$.

Squamous cell carcinoma is characterized by squamous cells with large nuclei and abundant eosinophilic cytoplasm. The cells exhibit prominent intracellular bridges and variable keratin formation, depending on the degree of differentiation. Poorly differentiated tumors lack keratinization and usually form solid sheets of cells with marked pleomorphism to the extent that require special studies to establish the nature of the tumor.

\section{Histologic variants of squamous cell carcinoma}

Several histologic variant of squamous cell carcinoma are identified. These variants are based on certain morphological features accordingly, which may or may not have prognostic implications. The following are the most reported variant in the literature and include basaloid, warty verrucous, papillary, spindle cell, adenosquamous, clear cell, acantholytic and lymphoepithelioma-like type.

Spindle cell carcinoma is rather rare and is composed of atypical spindle cells with whorled arrangement (Fig 1), which mostly come from immunosuppressed renal transplant patients. The tumor needs to be differentiated from desmoplastic melanoma, atypical fibroxanthoma or metastatic carcinoma with spindle cell features. Immunohistochemistry is of value in differentiating these entities [8].

Clear squamous cell carcinoma is another variant first described as squamous cell carcinoma with extensive hydropic changes. The cells appear glassy looking, due to accumulation of fluid, and can be easily mistaken for sebaceous cell carcinoma. The differential also includes other clear cell tumors such as clear cell acanthoma, clear cell hidradenoma, metastatic renal cell carcinoma, balloon cell nevus and melanoma [9]. 


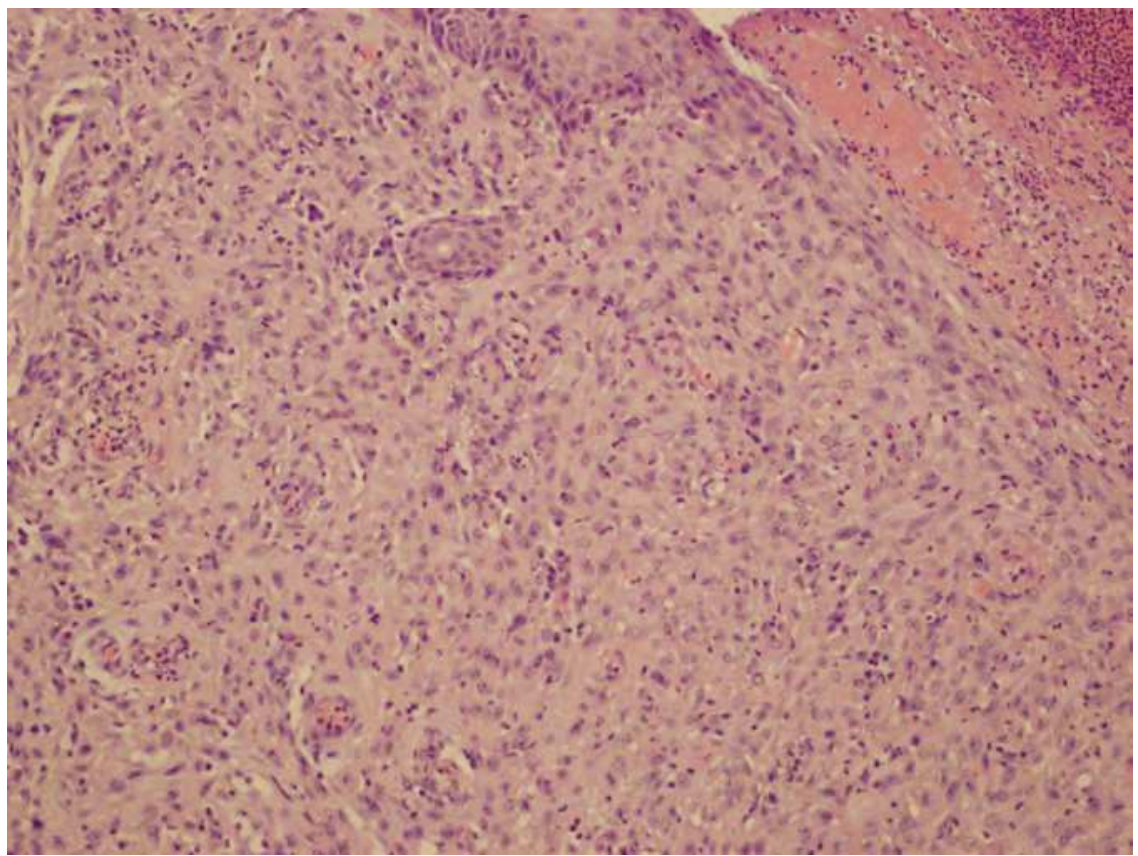

Fig. 1. Spindle cell variant of squamous cell carcinoma

Verrucous squamous cell carcinoma presents with rather non dysplastic epithelium with hyperkeratosis and elongation of the rete pegs. This is in contrast to the papillary variant of squamous cell carcinoma, which is characterized by malignant looking epithelium with papillary or exophytic architecture [10]. Adenosquamous cell carcinoma is very rare subtype, which is composed of admixed adenocarcinoma with squamous cell carcinoma. Mucin stain usually highlights the adenocarcinoma component.

Basaloid basal cell carcinoma is a rare variant of squamous cell carcinoma with more cases, which have been published since its first description in 1986 by Wain et al (11). These tumors affect both sexes but with predominance of male patients. They are frequently seen in the aerodigestive tract with most of the cases to be found in the tongue, floor of the mouth, the pyriform sinus, tonsil, and larynx [12]. These tumors have also been described in a variety of sites including nasopharynx, trachea, skin, cervix, bladder, thymus, anus, conjunctiva, and lung $[13,14,15,16]$. Clinically, patients have similar presentation to conventional squamous cell carcinoma depending on the site of the lesion.

Etiology and pathogenesis of basaloid cell carcinoma is similar to conventional squamous carcinoma. Most patients have a long history of smoking and alcohol drinking. In some cases there was a history of previous radiation to the head and neck region [17]. Both represent independent risk factors for the development of squamous cell carcinoma. Smokeless tobacco and other exogenous carcinogens such as occupational, environmental and nutritional factors may also play role in the pathogenesis of this cancer. EBV was detected in few cases using in situ hybridization technique from nasopharyngeal sites. 
Recent studies detected a higher frequency of HPV and HSV in basaloid tumors than in conventional squamous cell carcinomas of the head and neck [18]. Basaloid squamous cell carcinoma in non smoker young patients revealed infection with HPV, high risk genotype 16. The expression is so significant, to the extent that it led some authors to consider the expression may be important for the diagnosis of this type of squamous cell carcinoma. The prognosis of HPV induced carcinoma appeared to have better outcome than the HPV negative cases [19]. It is not practical to perform in situ hybridization and sequencing techniques on every single case of basaloid squamous carcinoma as this is technically demanding and can be performed mostly in special centers [20]. The cell of origin of these tumors has been suggested to be a multipotential cell, which is able to differentiate into multiple cell type. However, the most acceptable origin for these cells is that they are from the surface epithelium since there is dysplastic or carcinoma in situ changes with direct continuity within the invasive component.

The tumor is considered by many authors as high grade with more aggressive behavior [11.16]. These lesions are capable of distant metastases, deep invasion, local recurrence and lymph node involvement. The most common sites for distant metastasis are the lung and liver. Multifocal disease includes other sites in the head and neck, which were also documented [17] However, some controversy is still present regarding the prognosis and conflicting results, which have appeared in recent literature. Some published papers claimed they have similar prognosis to traditional squamous cell carcinoma [21]. The majority of these cases are found at an advanced stage, which could explain the poor clinical outcome and prognosis. No general guidelines are present regarding the management of this disease; however, most published reports recommend a combination of surgery and postoperative radiotherapy, in order to prevent local recurrence and distant metastases [12,14].

\section{Pathology of basal squamous cell carcinoma}

Macroscopic appearances of these tumors show flat or slightly raised or polypoid exophytic lesions with or without a central ulceration in most cases reported in the literature [3] Microscopic examination of these lesions show characteristic invasive growth appearance, shared by most lesions. Generally they are composed of ribbons and or cords of basaloid cells with peripheral palisading and closely resemble traditional basal cell carcinoma figure 2. This lesion comes from rare urinary bladder flat lesion from a 66-year-old man seen on cystoscopy. In addition, the cellular arrangements of these lesions can closely mimic adenoid cystic carcinoma, due to the glandular or cribriform pattern, and have a tendency to have intracellular deposition of eosinophilic hyaline material figure 3 . One of the major features of this tumor is that the cells exhibit high nucleocytoplasmic ratio and often have dense hyperchromatic nuclei and comedonecrosis may be seen in these tumor, figure 4, which was seen in a patient who presented with nasal sinus mass. This appearance represents common features of these lesions. Mitotic figures may be high and may include atypical forms. Careful search will reveal focal squamous differentiation with intercellular bridges or keratin formation, which is important for the accurate pathological assessment of these tumors. Another important feature of these lesions is dysplasia of the surface epithelium in cutanous neoplasm. Sometimes the tumor show true neural type rosette 
formation and other tumors may exhibit spindle shaped pleomorphic cells with elongated nuclei. Vascular or lymphatic invasion may also be present. In recent publication of cutanous basaloid squamous cell carcinoma, this tumor may also have rather large pleomorphic cells with big nuclei widely scattered throughout the lesion. These pleomorphic cells present no significant biological behavior. The immunoprofile of these tumors show consistent positive staining to high molecular weight cytokeratin antibody 34 $\beta \mathrm{E} 12, \mathrm{KL1}$, and MNF116, and focal staining for vimentin, EMA, CAM5.2, CK7, CEA, S100 and GFAP, and negative immunostaining for CK20, chromogranin, synaptophysin, BCL2, and Ber-EP4. Actin staining was positive in the basaloid cells and some cases were positive for CD99. More recent studies confirm strong and diffuse staining for P63 immunomarker in this tumor figure 5. Lastly, electron microscopic examination of samples may show tonofilaments and desmosome and do not demonstrate any characteristic findings, as the malignant cells show mainly undifferentiated cellular features, and the organelles are rather poorly developed(22).

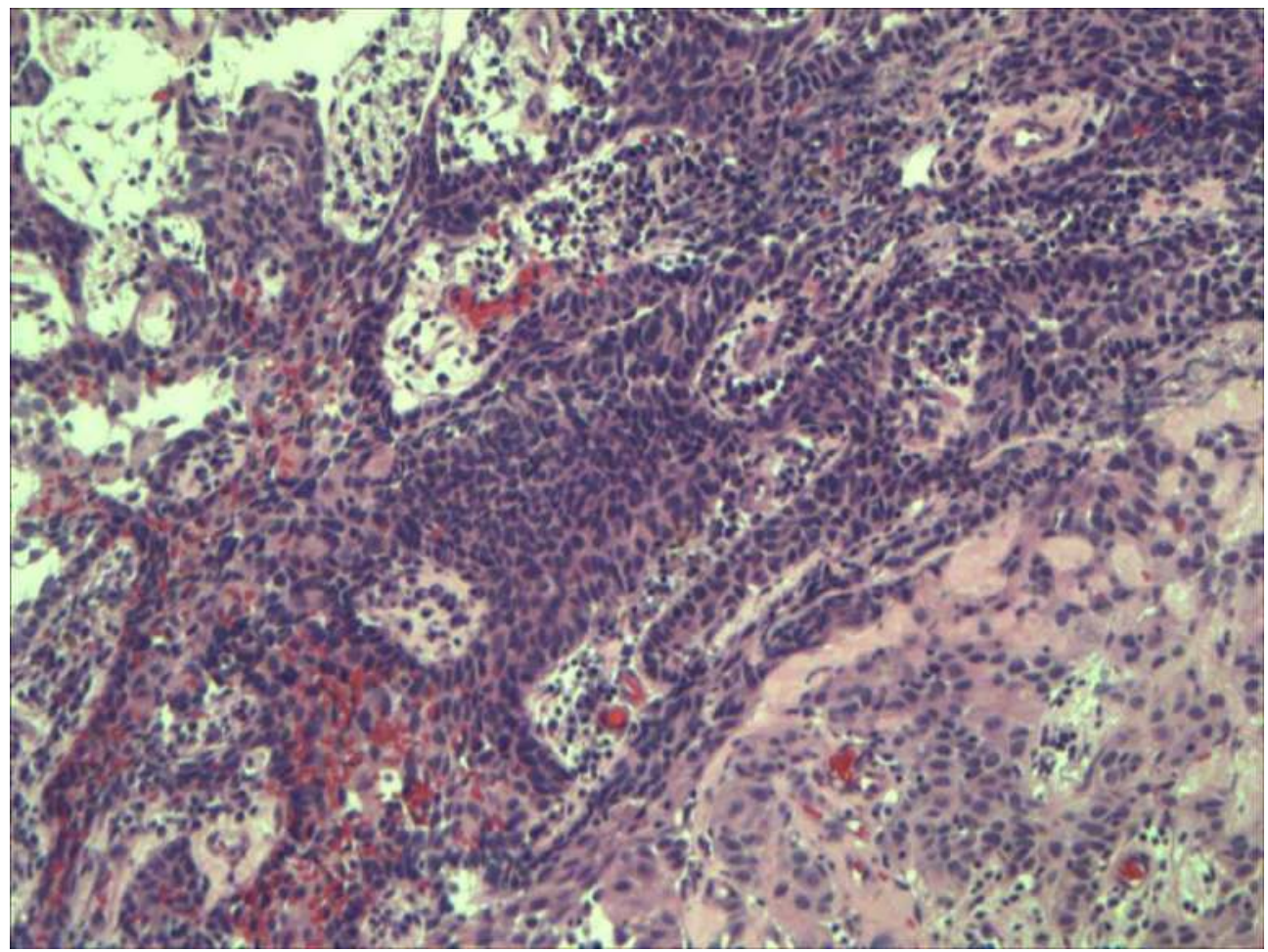

Fig. 2. Basaloid squamous cell carcinoma with peripheral palisading 


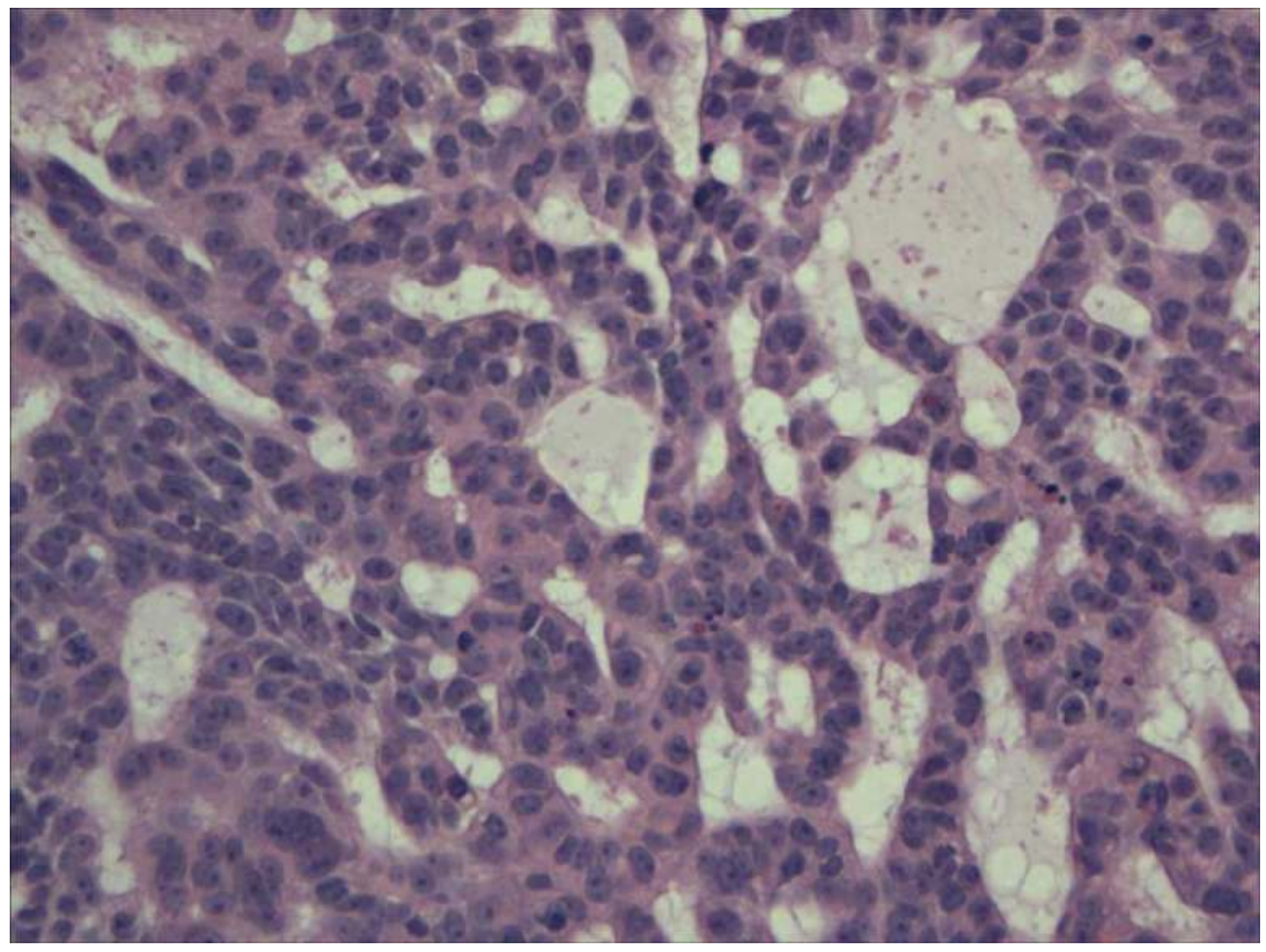

Fig. 3. Basaloid squamous carcinoma with glandular pattern 


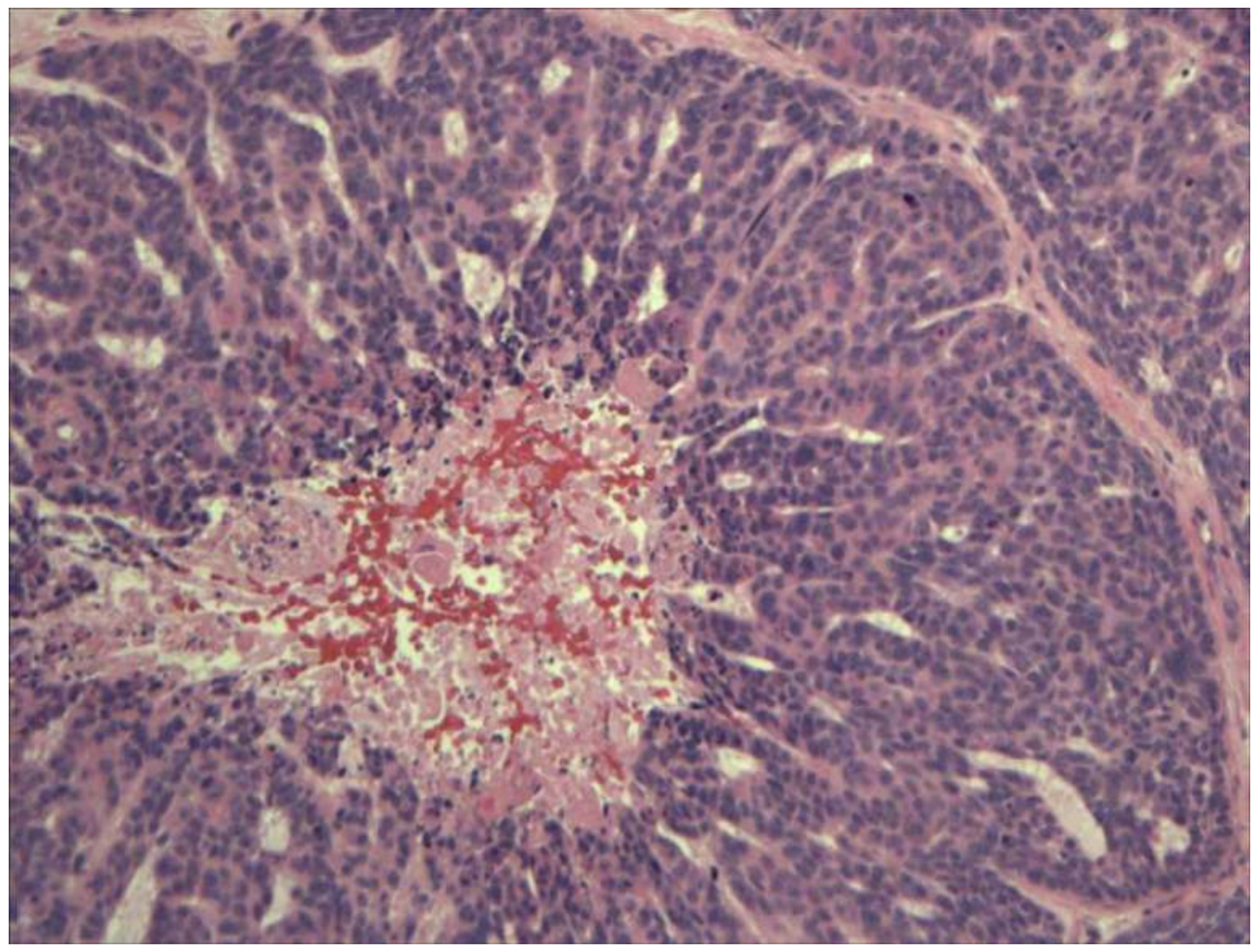

Fig. 4. The lesion shows prominent central necrosis 


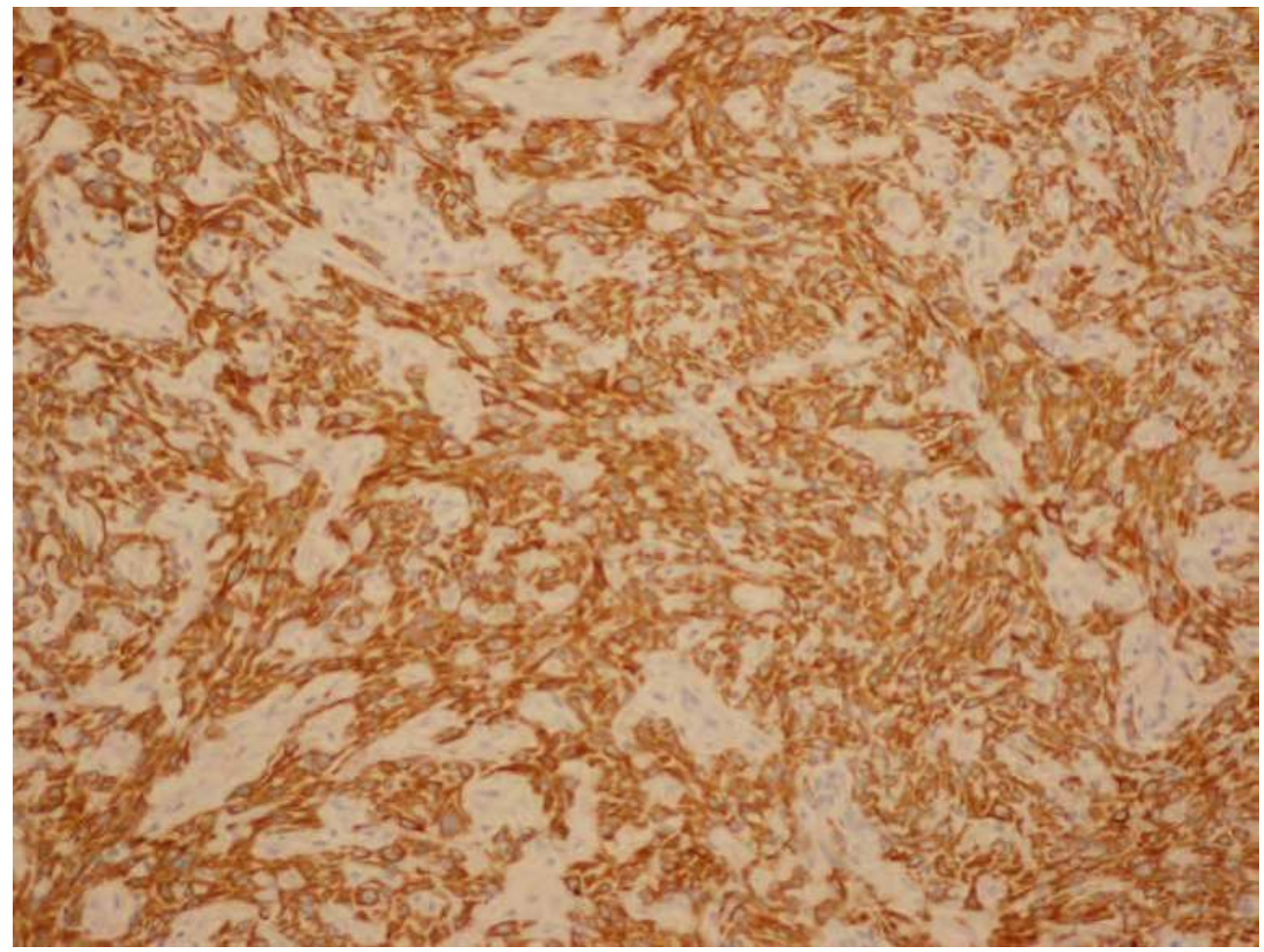

Fig. 5. Immunostaining with $34 \beta E 12$ 


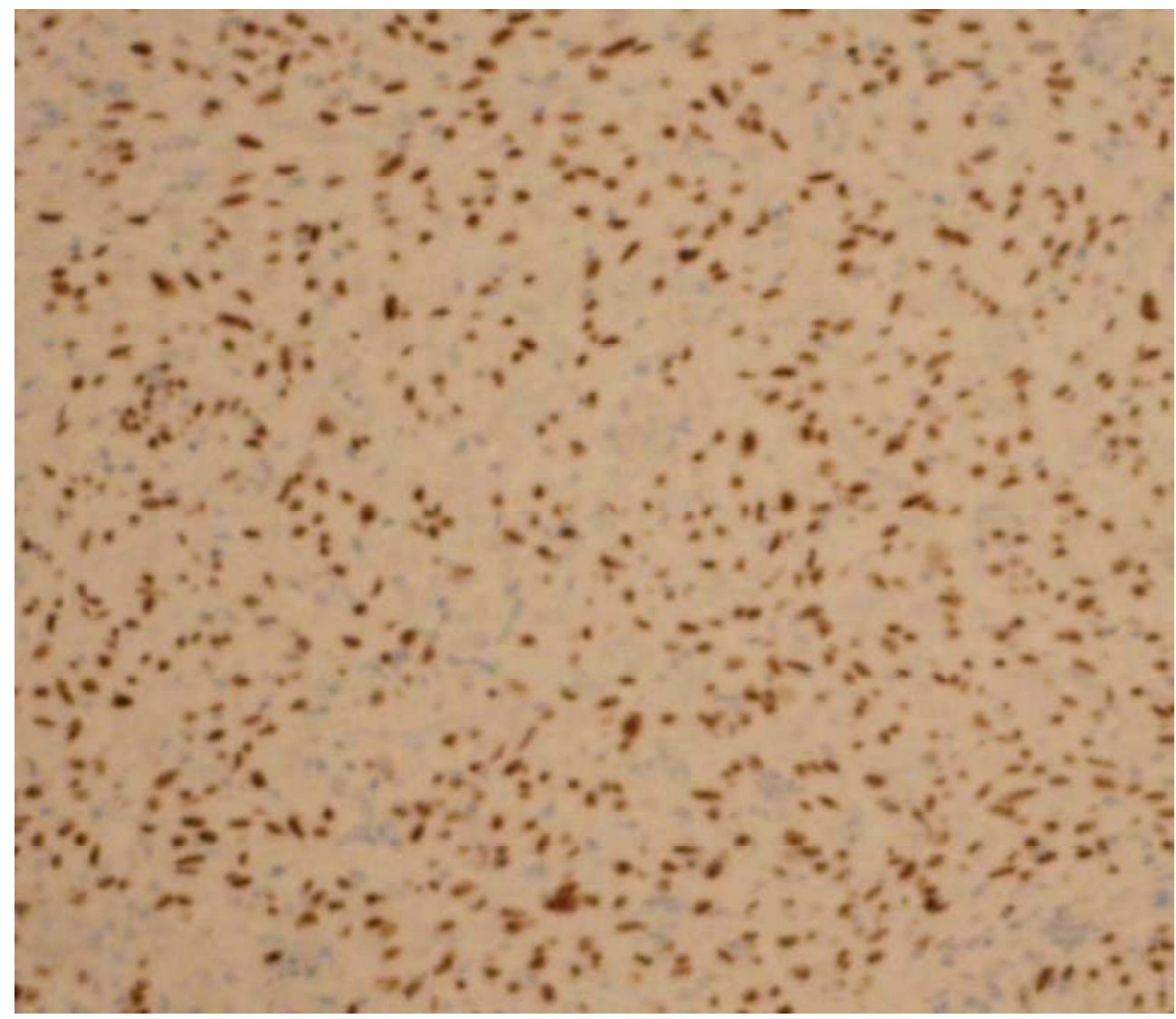

Fig. 6. Showing diffuse p63 positive malignant cell

The differential diagnosis of these tumors includes adenoid cystic carcinoma, small cell neuroendocrine carcinoma and other carcinomas depending on the anatomical sites.

Adenoid cystic carcinoma is characterized by basaloid-looking cells with predominant myoepithelial cells forming cribriform, solid or tubular structure. The tumor is slowly growing, less aggressive and with infrequent lymph node metastasis. Perineural invasion is a common feature of this lesion [23]. Immunohistochemistry show positive staining of the myoepthelial cells for S100, actin and calponin. The epithelial ductal cells of the tumor stain for cytokeratin, CEA and EMA. The stromal hyaline material can be highlighted with collagen IV and laminin. Small cell carcinoma is a more aggressive lesion with a different treatment approach. The tumor cells are positive for chromogranin, synaptophysin and dotlike staining for cytokeratin. These tumors are negative for $34 \beta \mathrm{E} 12$ marker, which is normally present in basaloid squamous cell carcinoma [17]. Skin basal cell carcinoma share histologic features with basaloid squamous cell carcinoma and need to be differentiate; however it lacks surface epithelial dysplasia, pleomorphism and the comedonecrosis seen in basaloid squamous cell carcinoma [17]. Adenosquamous carcinoma, which comprised of 
squalors and glandular differentiation, can have surface epithelial dysplasia. These lesions contain mucin and lack basaloid cells and peripheral palisading [24].

In conclusion, this variant of squamous cell carcinoma is reported in many sites and organs and present unique pathological and clinical features. This neoplasm is currently under more investigation to determine the nature and clinical behavior. The pathology of this entity is characterized by closely packed basaloid-looking cells with scanty cytoplasm. The cells are arranged in ribbons or with trabecular pattern. Occasional foci of squamouslooking cells are identified. The immunoprofile of these tumors are helpful to distinguish them from basal cell carcinoma, adenoid cystic carcinoma and small cell neuroendocrine carcinoma. The tumor cells are positive for epithelial marker 34B E12, EMA and P63.

Management of basaloid squamous cell carcinoma which is considered by many authors as more aggressive tumor requires radical excision followed by locoregional radiation and chemotherapy. For advance cases combination of radiotherapy and chemotherapy is a logical approach to control the disease. The overall disease free survival rate statically is slightly lower than in the conventional type of squamous cell carcinoma. Meanwhile some studies concluded that the prognosis is comparable to conventional type but the number of cases is to small to draw a definite conclusion. Metastatic disease is recorded in many patients with basaloid squamous cell carcinoma and it is advisable to perform metastatic work up. In conclusion the disease appears in most reported cases in the literature as more aggressive and capable of distant metastasis. [17, 25].

\section{References}

[1] Hurt, M.A, Santa Cruz, D.J Tumors of the skin in Daignostic histopathology of tumors 2nd Edition, Vol 2, Churchill Livingstone 2000.

[2] Glover MT, Deeks JJ, Raftery MJ, Cunningham J, Leigh IM. Immunosuppression and risk of non-melanoma skin cancer in renal transplant recipients. Lancet 1997;349:398.

[3] Ereño C, Gaafar A, Garmendia M, Etxezarraga C, Bilbao FJ, López JI Basaloid squamous cell carcinoma of the head and neck: a clinicopathological and follow-up study of 40 cases and review of the literature. Head neck pathol, 2008 Jun; 2(2):83-91. Epub 2008 Mar 21

[4] Silverberg SG, Ioffe OB. Pathology of cervical cancer. Cancer J. 2003 Sep-Oct;9(5):335-47

[5] Shinton NK. The histological classification of lower respiratory tract tumors. Br J Cancer. 1963, 17:213-21

[6] Radhi JM, Awad SM.Bilateral squamous cell carcinoma of the ovary;case report Br J Obstet Gynaecol. 1990 Sep;97(9):855-6.

[7] Powell JL, Stinson JA, Connor GP, Shiro BS, Mattison M. Squamous cell carcinoma arising in a dermoid cyst of the ovary Gynecol Oncol. 2003 Jun;89(3):526-

[8] Kanner WA, Brill LB 2nd, Patterson JW, Wick MR. CD10, p63 and CD99 expression in the differential diagnosis of atypical fibroxanthoma, spindle cell squamous cell carcinoma and desmoplastic melanoma J Cutan Pathol. 2010 Jul;37(7):744-50

[9] Requena L, Sánchez M, Requena I, Alegre V, Sánchez Yus E. Clear cell squamous cell carcinoma. A histologic, immunohistologic, and ultrastructural study J Dermatol Surg Oncol. 1991 Aug; 17(8):656-60.

[10] Chaux A, Soares F, Rodríguez I, Barreto J, Lezcano C, Torres J, Velazquez EF, Cubilla AL. Papillary squamous cell carcinoma, not otherwise specified (NOS) of the penis: 
clinicopathologic features, differential diagnosis, and outcome of 35 cases Am J Surg Pathol. 2010 Feb;34(2):223-30.

[11] Wain, S. L., R. Kier, R. T. Vollmer, and E. H. Bossen. 1986. Basaloid-squamous carcinoma of the tongue, hypopharynx, and larynx: report of 10 cases. Hum Pathol 17:1158-66.

[12] Choussy, O., M. Bertrand, A. Francois, E. Blot, H. Hamidou, and D. Dehesdin. Basaloid squamous cell carcinoma of the head and neck: report of 18 cases. J Laryngol Otol:1-6.

[13] Kwon, Y. S., Y. M. Kim, G. W. Choi, Y. T. Kim, and J. H. Nam. 2009. Pure basaloid squamous cell carcinoma of the uterine cervix: a case report. J Korean Med Sci 24:542-5.

[14] Nagakawa, H., K. Hiroshima, Y. Takiguchi, M. Yatomi, Y. Takahashi, M. Mikami, Y. Nakatani, and T. Kuriyama. 2006. Basaloid squamous-cell carcinoma of the lung in a young woman. Int J Clin Oncol 11:66-8.

[15] Neves, T. R., M. J. Soares, P. G. Monteiro, M. S. Lima, and H. G. Monteiro. Basaloid squamous cell carcinoma in the urinary bladder with small-cell carcinoma. J Clin Oncol 29:e440-2.

[16] Vasudev, P., O. Boutross-Tadross, and J. Radhi. 2009. Basaloid squamous cell carcinoma: two case reports. Cases J 2:9351.

[17] Wieneke JA, Thompson L, Weng BM Basaloid squamous cell carcinoma of sinonasal tract, cancer 1999;85.841-854

[18] Kleist B, Bankau A, Lorenz G, Jäger B, Poetsch M. Laryngoscope 2004 Different risk factors in basaloid and common squamous head and neck cancer.114(6):1063-8.

[19] Thariat, J., C. Badoual, C. Faure, C. Butori, P. Y. Marcy, and C. A. Righini. Basaloid squamous cell carcinoma of the head and neck: role of HPV and implication in treatment and prognosis. J Clin Pathol 63:857-66.

[20] Friedrich RE, Sperber C, Jäkel T, Röser K, Löning T Basaloid lesions of oral squamous epithelial cells and their association with HPV infection and P16 expression. Anticancer Res ;30(5):1605-12.

[21] Thariat J, Ahamad A, El-Naggar AK, Williams MD, Holsinger FC, Glisson BS, Allen PK, Morrison WH, Weber RS, Ang KK, Garden AS. Outcomes after radiotherapy for basaloid squamous cell carcinoma of the head and neck: a case-control study. Cancer 2008 Jun 15;112(12):2698-709.

[22] Hewan-Lowe, K., and I. Dardick.. Ultrastructural distinction of basaloid-squamous carcinoma and adenoid cystic carcinoma. Ultrastruct Pathol 1995; 19:371-81.

[23] Kim K H, Sung M W et al Adeniod cystic carcinoma of the head and neck.Arch Otolaryngol,Head Neck Surg 1994,120;721-726.

[24] Azorín D, López-Ríos F, Ballestín C, Barrientos N, Rodríguez-Peralto JL. Primary cutanous, adenosquamous carcinoma case report and review of the litreture .J Cutan Pathol. 2001 Nov; 28(10):542-5.

[25] Paulino A, Singh M, Shah A, Huvos A. Basaloid Squamous Cell Carcinoma of the Head and Neck. The Laryngoscope Volume 110, Issue 9, pages 1479-1482, September 2000 . 


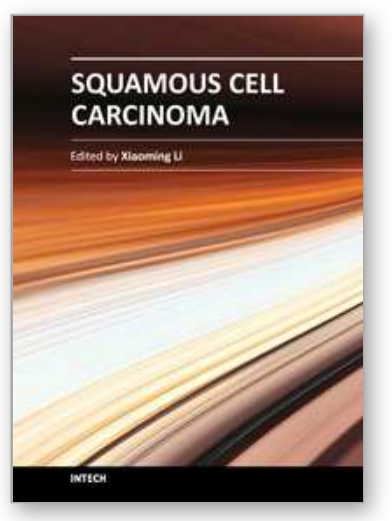

\author{
Squamous Cell Carcinoma
}

Edited by Prof. Xiaoming Li

ISBN 978-953-51-0024-9

Hard cover, 302 pages

Publisher InTech

Published online 03, February, 2012

Published in print edition February, 2012

This book points to some new areas for investigation on squamous cell carcinoma (SCC). Firstly, the features and management of some specific SCC is discussed to give the readers the general principles in dealing with these uncommon and sophisticated conditions. Some new concepts in adjuvant therapy including neoadjuvant therapy and gold nanoparticle-based photo dynamic therapy are introduced. Secondly, a detailed discussion of molecular aspects of tumor invasion and progression in SCC is provided with the emphasis on the roles of some important factors. The role of tumor microenvironment in head and neck SCC is specifically discussed. Thirdly, the roles of cancer stem cells (CSC) in cancer therapy of SCC are described. Molecular mechanisms involving therapeutic resistance and new therapeutic strategies targeting CSC are discussed in detail. Finally, other aspects concerning SCC are included, which involve the assessment, genetic manipulation and its possible clinical implications for the treatment of SCC.

\title{
How to reference
}

In order to correctly reference this scholarly work, feel free to copy and paste the following:

Jasim Radhi (2012). Basaloid Squamous Cell Carcinoma, Squamous Cell Carcinoma, Prof. Xiaoming Li (Ed.), ISBN: 978-953-51-0024-9, InTech, Available from: http://www.intechopen.com/books/squamous-cellcarcinoma/basaloid-squamous-cell-carcinoma

\section{INTECH}

open science | open minds

\author{
InTech Europe \\ University Campus STeP Ri \\ Slavka Krautzeka 83/A \\ 51000 Rijeka, Croatia \\ Phone: +385 (51) 770447 \\ Fax: +385 (51) 686166 \\ www.intechopen.com
}

\author{
InTech China \\ Unit 405, Office Block, Hotel Equatorial Shanghai \\ No.65, Yan An Road (West), Shanghai, 200040, China \\ 中国上海市延安西路65号上海国际贵都大饭店办公楼405单元 \\ Phone: +86-21-62489820 \\ Fax: +86-21-62489821
}


(C) 2012 The Author(s). Licensee IntechOpen. This is an open access article distributed under the terms of the Creative Commons Attribution 3.0 License, which permits unrestricted use, distribution, and reproduction in any medium, provided the original work is properly cited. 